\title{
Men's knowledge on body care: a cartographic study
}

\author{
Saberes dos homens sobre o cuidado com o corpo: um estudo cartográfico \\ Conocimento de los hombres sobre el cuidado corporal: un estudio cartográfico
}

Cleiry Simone Moreira da Silva'
ORCID: 0000-0002-5398-4926

Álvaro Pereira"

ORCID: 0000-0003-1899-7374

Paulo Sérgio da Silva'" ORCID: 0000-0003-2746-2531

Nébia Maria Almeida de Figueiredo'v ORCID: 0000-0003-0880-687X

Universidade Estadual de Roraima. Boa Vista, Roraima, Brazil. "Universidade Federal da Bahia. Salvador, Bahia, Brazil. I'Universidade Federal de Roraima. Boa Vista, Roraima, Brazil. "Universidade Federal do Estado do Rio de Janeiro. Rio de Janeiro, Rio de Janeiro, Brazil.

How to cite this article: Silva CSM, Pereira A, Silva PS, Figueiredo NMA. Men's knowledge on body care: a cartographic study. Rev Bras Enferm. 2020;73(5):e20180988. doi: http://dx.doi.org/10.1590/0034-7167-2018-0988

Corresponding author: Cleiry Simone Moreira da Silva E-mail: cleirynete@hotmail.com

EDITOR IN CHIEF: Dulce Barbosa ASSOCIATE EDITOR: Hugo Fernandes

Submission: 02-08-2019

Approval: 09-23-2019

\begin{abstract}
Objective: to identify men's knowledge on body care. Method: it is a cartographic study with a qualitative approach. The research was conducted with 70 men in the city of Boa Vista, state of Roraima. The strategy for data production was called the meeting. Participants were encouraged to think about epistemic units, care and body, from models that were recorded and their meanings transcribed for content analysis according to Bardin. Results: 282 units of decoded records such as body hygiene, sexual health and physical exercise were evidenced. In the decoding units, the conscious, functional male body is discussed, which serves for health professionals to think about caring approaches. Final considerations: cartographic forays allowed the male body to be recognized for its functionality, with structured knowledge on care in three dimensions: body hygiene, sexuality and sports practices.

Descriptors: Men's Health; Masculinity; Health Policy; Human Body; Nursing Care.
\end{abstract}

\section{RESUMO}

Objetivo: identificar os saberes dos homens sobre o cuidado com o corpo. Método: trata-se de um estudo cartográfico com abordagem qualitativa. A pesquisa foi realizada com 70 homens no município de Boa Vista, Roraima. A estratégia para a produção dos dados foi denominada de assembleia. Os participantes foram estimulados a pensarem as unidades epistêmicas, cuidado e corpo, a partir de modelagens que foram gravadas e, seus significados, transcritos para a análise de conteúdo segundo Bardin. Resultados: foram evidenciadas 282 unidades de registros decodificadas como higiene corporal, saúde sexual e prática de exercícios físicos. Nas unidades de decodificação, é discutido o corpo masculino funcional, tomado de consciência, que serve para os profissionais de saúde pensar abordagens de cuidar. Considerações finais: as incursões cartográficas permitiram reconhecer o corpo masculino da funcionalidade, com saberes estruturados sobre o cuidado em três dimensões: higienização corporal, sexualidade e práticas esportivas.

Descritores: Saúde do Homem; Masculinidade; Política de Saúde; Corpo Humano; Cuidados de Enfermagem.

\section{RESUMEN}

Objetivo: identificar el conocimiento de los hombres sobre el cuidado del cuerpo. Método: este es un estudio cartográfico con un enfoque cualitativo. La encuesta se realizó con 70 hombres en ela cuidad de Boa Vista, Roraima. La estrategia para producir los datos se llamó ensamblado. Se alentó a los participantes a pensar en las unidades epistémicas, el cuidado y el cuerpo, a partir de modelos que se registraron y sus significados se transcribieron para el análisis de contenido según Bardin. Resultados: se evidenciaron 282 unidades de registros decodificados, como higiene corporal, salud sexual y ejercicio físico. En las unidades de decodificación, se discute el cuerpo masculino consciente y funcional, que sirve para que los profesionales de la salud piensen en enfoques de cuidado. Consideracion finales: las incursiones cartográficas permitieron reconocer el cuerpo masculino de funcionalidad con conocimiento estructurado sobre el cuidado en tres dimensiones: higiene corporal, sexualidad y prácticas deportivas.

Descriptores: Salud del Hombre; Masculinidad; Política de Salud; Cuerpo Humano; Atención de Enfermeira. 


\section{INTRODUCTION}

As a starting point, it is appropriate to contextualize that studies on men's health are, in their nature, challenging. Most men seek professional follow-up only when faced with a health disorder. This is a worrying factor, especially when it comes to young individuals who should also spontaneously seek guidance on health promotion, preventive care and not only medical and curative care ${ }^{(1)}$.

Moreover, the limiting aspects of access to health services, of course, are economic, personal, political, physical, cultural, spiritual and historical, which affect men throughout their lives, from birth to death, invariably. From this perspective, it is urgent and necessary to develop strategies that facilitate the access of the male population to primary health services, with flexibility of care hours and inclusion of specific care actions for all age groups ${ }^{(2)}$.

Specifically, thinking about men's health in the process of caring for the body goes through the ways of living that present a multiplicity of knowledge arising from human growth and runs through the phases of the life cycle (child, adolescence, adult and elderly). Caring for the men's in this century of constant change requires new understandings, integrated knowledge, innovative approaches to care and all aspects that surround it such as: land, fauna and flora. These are elements present in daily life that invite health professionals to be aware of emerging knowledge and care practices designed today to care for the male population.

The men's body must be scientifically observed throughout its vital path, as it undergoes multiple determinations that unfold on the social plane from its way of being in the world and, consequently, to conceive health care. Male singularities that are practical objects of caring for health professionals, in the services that make up the Brazilian Health System (SUS - Sistema Único de Saúde) network, or even in the spaces where men's lives flow in all their biological, historical, social, political and sexual aspects.

These observations indicate clues of a subjective nature, which can easily be gained from men's knowledge of caring for their own bodies. Thus, in this investigation, two important aspects of men's daily life are recognized. The first is the determination of the social contexts in which they are inserted, and the second, their behavior towards health, such as alcohol abuse, smoking, aversion to the adoption of physical activity and leisure practices, inadequate diet and search for the services that compose them. the SUS network. This only for exams and the use of medications that meet a certain health compromise ${ }^{(3)}$.

When thinking about the structured knowledge on caring for their own bodies, it is necessary to consider that men are affected, in a particular way, by the orientations coming from the family environment. It should also be considered that men are influenced by gender, marital experience, employability, relationship education, sexuality, as well as all the conditions that are directly involved in health and disease processes ${ }^{(4)}$.

All these statements invite to question the inclusion of men in care processes, politically scripted. This means that the production of care is directed to the prevention of chronic diseases, sometimes disregarding knowledge that was conveyed and produced, from birth, family education, school, college and aging itself.

However, it is considered extremely appropriate to follow the guidelines of public policies directed at this population. They are recent and have underlined the claim that health professionals recognize that the big global challenge in working with men is getting them to health services before they are sick, especially in chronic non-communicable health deviations and degenerative diseases such as Systemic Arterial Hypertension, Diabetes Mellitus and Cancer ${ }^{(5-6)}$.

In order to try to reduce the health problems of men ${ }^{(7-8)}$, a Brazilian National Policy for Comprehensive Care to Men's Health (Política Nacional de Atenção Integral à Saúde do Homem) is discussed that, from the perspective of health professionals, should consider, in its implementation, the differences regarding to the lifestyle of men, their insertion in the workforce, among other aspects.

Thus, it is possible to investigate men' knowledge on care of their own body, without losing sight of the political guidelines directed to the male population. The search is to know about this body-man inserted in a social space, which needs various care for disease prevention and health promotion at all times of his life. They are considered to be subjects driven by emotional flows and affected by political and economic processes.

Based on these meanings, the present study enters a new space, a place where knowledge on body care is built, but not uncommon, if the same thoughts about the sick man are kept. With this reflexive line, the following guiding question emerges from this investigation: what are the emerging knowledge coming from men about caring for their own bodies?

Thinking about other questions outside the physically ill male body implies understanding the man about new perspectives: health care that presents itself as a knowledge gap to be studied in the health plan, especially in nursing.

\section{OBJECTIVE}

To identify men's knowledge on body care.

\section{METHODS}

\section{Ethical aspects}

The research followed the guidelines provided for in Resolution 466/2012 of the Brazilian National Health Board (Conselho Nacional de Saúde). The research project was submitted to the Research Ethics Committee (REC) and approved in September 2017. All data production was preceded by reading and signing the Informed Consent Form, and the Consent Form, in the case of underage participants. It should be noted that the anonymity of participants in this investigation was maintained by the use of the word Man, followed by ordinal sequence.

\section{Theoretical-methodological framework}

The method used in this investigation was the cartographic ${ }^{(9)}$. The choice of cartography selection makes traveling researchers, starting from established research models, to seek innovative study designs, emerging men's knowledge that intertwine body and contextualized care with health. It is noteworthy that the research is methodologically based on theorists Gilles Deleuze and Felix Guattari ${ }^{(10)}$. 


\section{Type of study}

It is a descriptive research with qualitative approach. Regarding qualitative research, it enables the researcher to answer more particular questions. It does not seek the truth, which is often sophistically treated as a quantification of reality. What qualitative research insistently seeks is to understand and interpret as faithfully as possible the internal logic of the subjects who study and give knowledge of its truth ${ }^{(11)}$. It should be noted that this research met all the criteria listed in the COREQ TOOL.

\section{Methodological procedure}

Two meetings were held. The first meeting with the men took place in September 2017, in the afternoon from 13h to $15 \mathrm{~h} 30$. The second meeting took place in December of the same year at night from $19 \mathrm{~h}$ to $20 \mathrm{~h} 20$. At these meetings, two researchers discussed with study participants problem-themes that specifically deal with care and body.

\section{Study setting}

The study was conducted in Boa Vista, capital of the state of Roraima, located in the Legal Amazon. The municipality, located in the extreme north of Brazil, is currently suffering the impact of unbridled immigration, being geographically delimited by the border with two countries (English Guiana and Venezuela). The municipal network of Primary Health Care is territorialized in 06 macro areas. These regions comprise 55 Family Health Strategy (FHS) teams and 17 Oral Health Teams distributed in 32 Basic Health Units (BHU).

The context chosen for the study was a state school and a Higher Education Institution ( $\mathrm{HEI})$, within the scope of a $\mathrm{BHU}$, randomly selected from a draw. The selection of the two scenarios of scientific investigation is justified by two elementary aspects: expressive concentration of the male population in these investigative fields and for presenting a comfortable space for the meetings with study participants.

\section{Data source}

The social group involved in this investigation consisted of 70 men. The selection of these participants met the following inclusion criteria: men aged 12 to 60 regularly enrolled in secondary and higher education institutions. Women, men who refused to participate in the investigation, men who missed one of the two data production meetings, adolescents without permission from legal guardians and foreigners were excluded from the investigation. At the end, 40 men linked to the state school and 30 men from HEls were accounted for.

Overall, the social group involved in this research is characterized by an average age between 18 and 41 years. Most marital status evidenced was single followed by married. The three states of greatest origin of participants, in order of expressiveness, were Roraima, Pará and Maranhão. The most prominent professionals in this population were civil servants, nursing technicians and salespeople, whose most designated religions were Catholic and Evangelical.

\section{Collection and organization of data}

In meetings, a semi-structured interview script was used containing questions that addressed the following themes: man's relationship with health services, influences suffered by them to learn to selfcare, self-care modes and (un) pleasant aspects of their own body. All speeches were recorded in MP3 Player, using a pre-programmed fixed camera as accessory feature for data recording. After this step, all the data produced were transcribed for analysis.

The raw data analysis process followed the theoretical-analytical framework of content provided by Laurence Bardin ${ }^{(12)}$. This textual analysis proposal is characterized by systematic and objective procedures for describing the content of messages that allow the inference, here, of knowledge that men from the far north of Brazil have about body care.

Registration units from the analytical process were organized in the category entitled"Knowledge on care with the functional body from men in the far north of Brazil". The category consisted of three decoding units, namely: body care from the perspective of body hygiene; body care in the sphere of sexuality; body care in the dimension of physical activity. For this, data were organized in a representative scheme about the functional body and the main statements of the men arranged in the decoding units in order of expressiveness.

\section{RESULTS}

Care contents produced in meetings with men totaled 282 record units. The set of analytically decoded meanings was enhanced within the meetings by performing representative modeling on the epistemic units "care" and "body".

A functional body provides multiple identities and existential balance by considering its organic nature in permanent $21^{\text {st }}$ century contours. In this category, we talk about a male body, whose functionality is at the center of the discourses, aware that serves for health professionals to think about care approaches. As a way to highlight these findings, about what was called the functional body, follows Figure 1.

The men's functional body thought in interface with knowledge on his health is a puzzle. This structure obliges health professionals to develop permanent analyzes for the implementation of their clinical care conducts to this population. Thus, studying the male body went to the following statements representative of the first decoding unit that deals with body hygiene:

[...] I take a shower, brush my teeth, brush my feet and cut my nails. (Man 1)

[...] take a good shower, wash the intimate parts always with plenty of water, make the expression of the foreskin to remove all dirt and accumulation of dirt. Another thing is to brush your teeth and feet well. Taking care of beard and hair. (Man 2)

[...] I take care of my body, but, so, the basics, like brushing my teeth, taking a shower, washing my hands before going to eat and after going to the bathroom. So very basic. (Man 4)

Care is the same as taking a bath, starting with the head, washing the hair well after the rest of the body, skinning the penis to 
remove the "onion", and then forgetting to brush the feet and cut the nails. (Man 5)

[...] the importance of taking care of the body. The intimate hygiene of washing the parts that have to skin, brush the teeth, eye care, ears, bowel, stomach and even the head itself [...] (Man 6)

[...] shower with soap and water, always starting from head to toe, washing the main: the penis. Brush your teeth, wash your hands, take care of your whole body. (Man 7)

The body must be clean to prevent disease. Always wash your hands, brush your teeth after every meal, shower at least twice a day, cut your nails and hair. (Man 8)

[...] washing from head to toe, everything in the body, part by part, because I understand that if something is missing accumulates dirt and from two or three days begins to stink and you get sick. (Man 10)

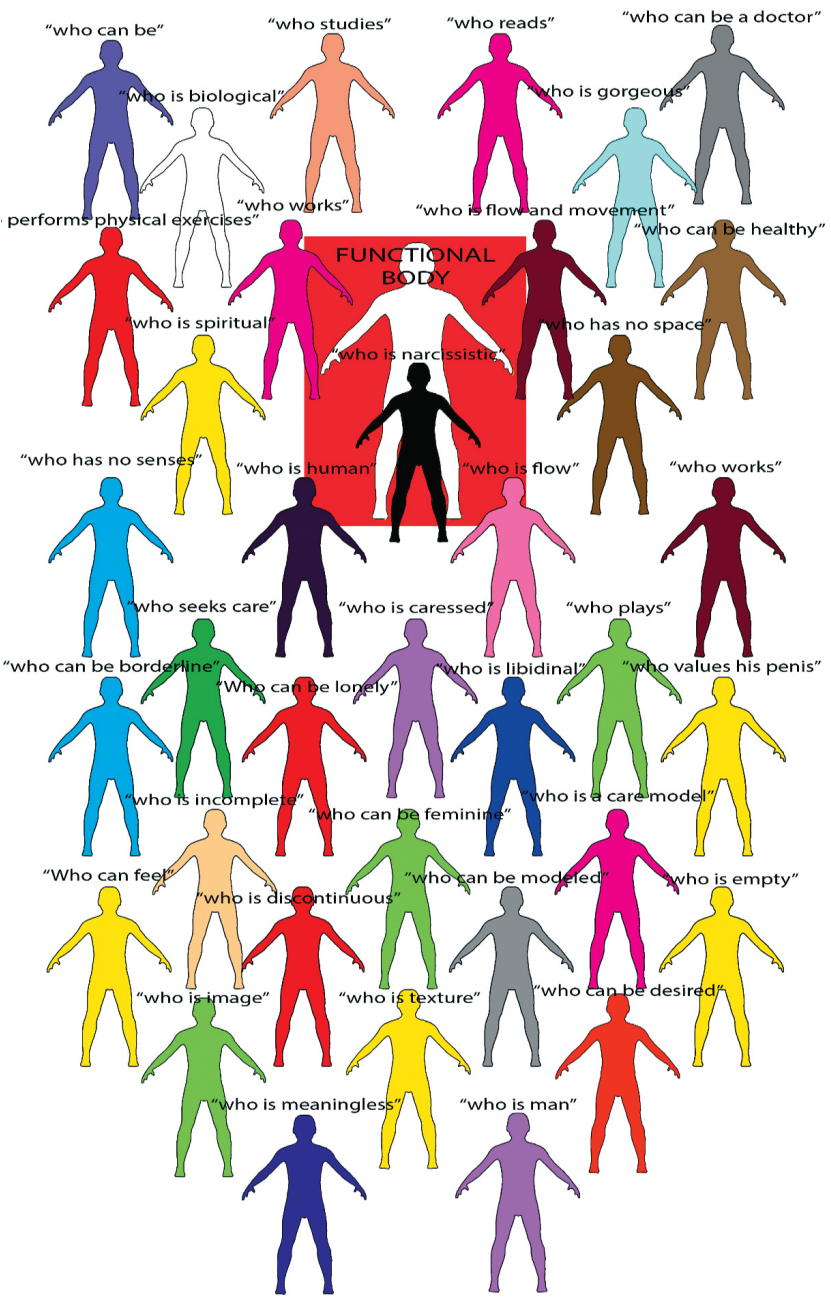

Figure 1 - Functional body produced in care modeling, Boa Vista, Roraima, Brazil, 2018

As a way of favoring the understanding of knowledge that men have about body care, they follow illustratively in the second unit of decoding of the statements that consider sexuality as a dimension of care. A male body that presents a physiological, individual, historical, social language. Body that lives health or has experienced illness processes that are difficult to access when it is considered that sexuality is still a veiled, hidden, forbidden theme that is kept in the silence of the bodies when they enter care scenes.

[...] / always watch for any signs in the penis that may appear and try to resolve soon. (Man 1)

[...] the sexual part of the diseases that can give to the penis is important in body care. (Man 6)

[...] / seek to prevent sexual diseases [...] (Man 8)

[...] make sure you don't have something wrong with him, such as a wound, discharge, wart, and you can be petted to see if he reacts. But all this to know if it is well and working well. (Man 9)

[...] I'm careful when having sex with women, sexual diseases are dangerous [...] (Man 11)

[...] I learned to take care of myself at school, especially to prevent prostate cancer and sexual diseases. (Man 23)

[...] at least once a year I go to the doctor to find out if there are any problems with the prostate, the penis, to prevent disease, and even sexual impotence. (Man 25)

[...] take care of the intimate parts to prevent sexual diseases. (Man 30)

The discovery of a body ideology of men pointed in the third decoding unit for physical exercise, represented here by walking and sports activities, as a structured knowledge on care. It should be said that these men have learned to recognize themselves within an exercise practice and are gradually seeking to adjust their time to this lifestyle. These reflections can be evidenced in the illustrative statements presented below:

I take care of myself by exercising. (Man 15)

[...] / walk sometimes. (Man 18)

[...] I've always played soccer in my life, this is the way to take care of my body. (Man 20)

\section{[...] I don't exercise regularly, but I walk. (Man 21)}

[...] else, I do physical exercises. (Man 22)

[...] I do physical exercises [...] (Man 27)

I take care of myself and do what I can[...] I walk sometimes. (Man 29)

[...] I try to do daily physical exercises [...] (Man 30)

This scientific approach points out that the contextualized care in the living of men is the origin of all life events, in the cultural matrix and in the regional diversities of Brazil. Specifically, in the far north, mapping the men who inhabit the territory of Roraima, represented by the city of Boa Vista, allowed to identify 
body hygiene, sexuality and physical exercise as textures of the male functional body to be discussed in the field of health care.

\section{DISCUSSION}

Discussions were directed to escape considerations. There is an escape from what is commonly thought of as structured knowledge on caring for men, especially when they point out that taking care of one's health is placing such a responsibility on someone or someone. These may be technologies represented by equipment and examinations or people characterized as healthcare professionals and caregivers ${ }^{(13)}$.

One must think about the geographical location of men, their genetic and historical memory, which concerns a new state, now assaulted by unbridled immigration from the surrounding countries, which is designing new territories and a new geography. In this regard, it should be emphasized that the city of Boa Vista was designed to be a modern center, following the European pattern. The project of the capital has large, well-lit spaces, numerous leisure places surrounded by gardens, which safely invites the population to perform physical activities.

Built and implanted by several miscegenates, eighty percent of the people who have been since its inception migrated from the South, Southeast, North and Northeast of Brazil. Their natives were given more texture of race, color and habits. This without considering the genetic memories, historical markings, the indigenous nations themselves, almost owner of all the territory of Roraimense (form Roraima) and what is not yet said of them as lived custom.

Textures of the Roraimense male functional body have been decoded beyond what works organically well. Bodies modeled by men in the meeting made it possible to think of comprehensive health care based on care needs, barriers to self-care and coping strategies used by professionals to implement clinical conducts ${ }^{(14)}$.

Bodies that study, dream to specialize, considered beautiful, libidinous, healthy, capable of performing political, spiritual, aesthetic movements, that seeks care, plays, values the penis, feels desired, devoid of social meanings, and finally, is working man.

These decodes are nomadic, thought of by young, adolescent, and adult individuals who modeled and spoke of their bodies as if they were searching for themselves. A functional man has a decoded narcissistic layer as he becomes a family man, out of a desire to have male children, overvaluation of his genital organ modeling, and concerns about health deviations that affect them, such as sexual impotence, sexual disease, and prostate cancer ${ }^{(15)}$.

In some moments, it was necessary to stop, think and demystify ideas of what is socially instituted as a body, especially when thinking about gender and marital relations ${ }^{(16)}$. They are stallion men, strong, beautiful, free and who cannot cry or show their weaknesses. Even considering this narcissistic nature, they modeled themselves incomplete, that is, without feet, without hands, with parts of the human senses: hearing, sight and smell.

It is a modeled functional body that shows texture of the presence and absence of the senses. Crystallized concretely as scenes of aesthetic production in the modeling clay that they themselves had never seen. Images created and signed as their human copies, in the dimensions of their creativity, mixed and hidden in their own stories, memories and self-awareness.

It is a body that can be considered by health professionals within the scenes of care as conscious. The functional body provides the identity and existential balance, considering its biological nature, which in this century is in permanent retouching, especially when they claim to have knowledge related to body hygiene, sexuality and the practice of physical activities ${ }^{(17)}$. These men indicated, in this study, knowledge on care with their own body that are of the "philosophical-existential", "philosophicalclinical" and "philosophical-spatial" order. These are themes that can be addressed today with care actions performed in the men's health care network.

They are men whose knowledge has been structured from a multiplicity of agencies ${ }^{(10)}$. They now form homes and raise their fragile, strong, affectionate children who are already stronger to express their suffering, crying, and, as such, can freely position themselves politically and critically. These men can also hide because they are still afraid and recognize that they are not just muscle and physical strength.

This is the meaning of care and body built in this study, structured in the form of knowledge when men mean body hygiene, the valuation of sexuality, whose center of care is the penis itself and even when they recognize in the daily life the need to perform some physical activity. An investigation guided by the look of nursing within the health area, but which can be interdisciplinary.

With this dimension, the functional man's body can reveal itself, hide itself, get lost or find itself in health care streams with various professionals. It is believed that in these care encounters, it is necessary an interdisciplinary approach that considers the knowledge that inhabits the man's body, within the actions of caring for, go beyond the dirty, sedentary, powerless body that presents Sexually Transmitted Infections ${ }^{(18)}$.

It is necessary to look for new ways especially in the services that make up Primary Health Care to work on family planning, especially if it is beyond the control of sexuality and unwanted paternity with feelings of guilt. Despite existing studies on the accessibility of men to health services, it is still urgent to identify all the reasons for not seeking the male population for health services. Only then will it be possible to determine the role of these men in services by implementing specific strategies that fully meet their health and disease demands and needs ${ }^{(19)}$.

The findings provide the exact notion of how programs and projects can be thought to take care not only of men, but of understanding the theorizing of language about the body and its representations, meaning constructions that systematize knowledge on people and care. With this position, one speaks of a clinic of the senses; look to acquire a true decoder power of the functional body of man; listen and listen to their knowledge to think about care behaviors that are resolute.

\section{Study limitations}

Generalizing has not been possible yet. The considerations that have been made are challenging and imply men's health, especially in the deconstruction of the little that is known about them in the plane of knowledge on body care, considering those who live in the far north of the country. Certainly this moment of 
the study invites us to review the clues of cartography, to return to trace again men's knowledge in new territories and contexts to reach the conclusion that the triad hygiene-sexuality-physical activity should be a cross-sectional theme in the established meetings of health professionals with men.

In light of the text, it is necessary to consider as a methodological limitation its strictly content analytical character, which makes the dimension of expression present in the production of data does not appear in the cartographic practice of this investigation. In this perspective, cartography, as a methodological guideline in the field of qualitative research, must also epistemologically highlight the dilation of the meanings of analysis.

In addition, the non-participation of the indigenous and immigrant population in this research is recognized, especially those of Venezuelan and Guyanese origin. Therefore, it was recognized that knowledge on care that was produced by the functional bodies of men was not crossed by the indigenous habits and customs so present in this territory. It is also worth mentioning that the study was not impacted by the current strong immigration, which disregarded decoding elements of being a man, as well as knowledge on care that comes from another culture.

\section{Contributions to nursing}

The study incorporates men's knowledge to think about the implementation of nursing behaviors in interface with the various professionals who make up the health area. The decoding of the male body, as functional, opens the way for the expansion of services and programs of attention to men. When structuring care models that go beyond the disease, Being-Man is considered in its ecological spaces affected by issues of gender, power, desires and affective flows.

This functional man body is the object and subject of nursing care. In this sense, knowledge emerged from the methodological application of cartography. Thus, at the level of subjectivity, the cartographic method was able to incorporate qualitative evidence for nursing, from an aesthetic and political perspective. Certainly, taking this approach to investigate the body-care duality in nursing alone involves a bet on contemporary thinking in an attempt to overcome the isolation of knowledge to raise new questions about human health that had not yet been raised.

Thus, it is believed that the results of this investigation enable in nursing practice new ways to take care of men. These pathways transcend the limits of disease man. It is necessary to recognize, in the male body, other dimensions of care, represented here by body hygiene, sexuality and physical activity as a way to promote health. In addition, these three dimensions of knowledge consider situational diagnoses for nurses and health managers to improve care policies for this population.

\section{FINAL CONSIDERATIONS}

The identification of knowledge on caring for men's bodies in living spaces allowed us to make considerations that are temporal. Knowledge is from now and runs in the threads of history to project into tomorrow, especially when caring spaces are built. Health policies were devised, and professionals with specific skills positioned to take care of them.

Body care and prevention of illness are born within the family and are strengthened in teaching during the stages of life, in adolescence, in adulthood, being extended until aging. The research shows that the man, decoded as functional, who is territorialized in the far north of the country, has the desire to want to take care of the body in three dimensions: body hygiene, care with sexuality and performance of sports practices.

Based on this, the study presents conclusive findings that identify how structured male knowledge on body care, from the perspective of body hygiene: bathing, brushing teeth, washing the genitals, cutting nails, beard and hair. In the sphere of sexuality, continuous inspection of the genital organ, prevention of sexually transmitted infections and seeking health services to treat sexual impotence were identified. Finally, in the dimension of physical activities, it was evidenced the practice of physical exercises represented by walking and playing soccer.

Cartographic incursions in the meetings, using modeling techniques, allowed us to decode the man-body as what he studies, reads, is a biological being, exercises, works, is flow and movement, can be healthy, is spiritual, is narcissistic, has no space, is meaningless, is human, is flow, works, seeks care, is caressed, plays, can be borderline, is supportive, is libidinal, values the penis, is incomplete, can be feminine, presents models of care, feels, is discontinuous, may be meaningless, is image, is texture, is empty and may be desired.

With the certainty of the unfinished, it is believed that this knowledge and meanings about the functional body of men, in their intimate relationship with health, can contribute to the processes of care performed by nursing. It may also benefit the development of interdisciplinary practices capable of considering existential, clinical and spatial dimensions in the various SUS contexts.

\section{REFERENCES}

1. Arruda GO, Marcon SS. Inquérito sobre a utilização dos serviços de saúde por homens adultos: prevalências e fatores associados. Rev LatinoAm Enfermagem. 2016;24:e2685. doi: 10.1590/1518-8345.0296.2685

2. Silva AN, Silva SA, Silva ARV, Araújo TME, Rebouças CBA, Nogueira LT. A avaliação da atenção primária a saúde na perspectiva da população masculina. Rev Bras Enferm. 2018;71(2):255-63. doi: 10.1590/0034-7167-2016-0651

3. Arruda GO, Marcon SS. Comportamentos de riscos à saúde de homens da região Sul do Brasil. Texto Contexto Enferm. 2018;27(2):e2640014. doi: 10.1590/0104-070720180002640014 
4. Sousa AR, Pereira A, Paixão GPN, Pereira NG, Campos LM, Couto TM. Repercussions of imprisonment for conjugal violence: discourses of men. Rev Latino-Am Enfermagem. 2016;24:e2847. doi: 10.1590/1518-8345.1569.2847

5. Bidinotto DNP, Simonetti JP, Bocchi SCM. Men's health: non-communicable chronic diseases and social vulnerability. Rev Latino-Am Enfermagem. 2016;24:e2756. doi: 10.1590/1518-8345.0735.2756

6. Huang B, Appel HB, Nicdao EG, Lee HJD, Ai AL. Chronic conditions, behavioral health, and use of health services among asian american men: the first nationally representative sample. Am J Men's Health. 2013;7(1):66-76. doi: 10.1177/1557988312460885

7. Ministério da Saúde (BR).Secretaria de Atenção à Saúde. Departamento de Ações Programáticas Estratégicas. Plano de ação nacional (20092011) da Política Nacional de Atenção Integral à Saúde do Homem. Brasília: Ministério da Saúde; 2009.

8. Alvarenga WA, Silva SS, Silva MEDC, Barbosa LDCS, Rocha SS. Política de saúde do homem: perspectivas de enfermeiras para sua implementação. Rev Bras Enferm [Internet]. 2012 [cited 2018 Nov 30];65(6):929-35. Available from: http://www.scielo.br/pdf/reben/v65n6/a07v65n6.pdf

9. Silva PS, Figueiredo NMA. Pesquisa cartográfica: reflexões teóricas e metodológicas para enfermagem. Texto Contexto Enferm [Internet]. 2018 [cited 2018 Nov 30];27(4):e5610016. doi: 10.1590/0104-07072018005610016

10. Deleuze G, Guattari F. Mil Platôs: Capitalismo e esquizofrenia: volume I. São Paulo (SP): Editora 34; 1995.

11. Minayo MCS. Qualitative analysis: theory, steps and reliability. Ciênc Saúde Coletiva. 2012;17(3):621-6. doi: 10.1590/ S1413-81232012000300007

12. Bardin L. Análise de Conteúdo. 1 ed. São Paulo: Edições 70, 2011.

13. Queiroz TS, Rehem TCMSB, Stival MM, Funghetto SS, Lima LR, Cardoso BG, et al. How do old men take care of their own health in Primary Care?. Rev Bras Enferm. 2018;71(Suppl 1):554-61. doi: 10.1590/0034-7167-2017-0131

14. Cavalcanti JRD, Ferreira JA, Henriques AHB, Morais GSN, Trigueiro JVS, Torquato IMB. Integral Assistance to Men's Health: needs, barriers and coping strategies. Esc Anna Nery. 2014;18(4):628-34. doi: 10.5935/1414-8145.20140089

15. Owens OL, Jackson DD, Thomas TL, Friedman DB, Hébert JR. Prostate Cancer Knowledge and Decision Making Among African-American Men and Women in the Southeastern United States. Int J Mens Health [Internet]. 2015 [cited 2018 Nov 30];14(1):55-70. Available from: https://www.ncbi.nlm.nih.gov/pmc/articles/PMC4505933/

16. Paixão GPN, Pereira A, Gomes NP, Campos LM, Cruz MA, Santos PFM. A experiência de prisão preventiva por violência conjugal: o discurso de homens. Texto Contexto Enferm. 2018;27(2):e3820016. doi: 10.1590/0104-07072018003820016

17. Medeiros PA, Streit IA, Sandreschi PF, Fortunato AR, Mazo GZ. Participação masculina em modalidades de atividades físicas de um programa para idosos: um estudo longitudinal. Cienc Saúde Coletiva. 2014;19(8):3479-88. doi: 10.1590/1413-81232014198.16252013

18. Genz N, Meincke SMK, Carret MLV, Corrêa ACL, Alves CN. Doenças sexualmente transmissíveis: conhecimento e comportamento sexual de adolescentes. Texto Contexto Enferm. 2017;26(2):e5100015. doi: 10.1590/0104-07072017005100015

19. Vieira KLD, Gomes VLO, Borba MR, Costa CFS. Atendimento da população masculina em Unidade Básica Saúde da Família: motivos para a (não) procura. Esc Anna. 2013;17(1):120-7. doi: 10.1590/S1414-81452013000100017 